\title{
GRAMMAR-TRANSLATION METHOD AFFECTS STUDENTS' READING COMPREHENSION AND MOTIVATION
}

\author{
Rizky Kurniawan ${ }^{1}$, M. Zaini Miftah ${ }^{* 2}$, Zaitun Qamariah ${ }^{3}$ \\ 1,2,3 Department of English Language Education, Faculty of Teacher Training and Education, Institut \\ Agama Islam Negeri Palangka Raya \\ * Corresponding Author Email: m.zaini.miftah@iain-palangkaraya.ac.id
}

\begin{abstract}
In English teaching, teaching methods should be applied in the classroom for the successful teaching activity. It is believed that the Grammar Translation Method (GTM) is effective for teaching reading comprehension and motivating students. This study investigated the effect of GTM on students' reading comprehension and their reading motivation at SMAN 4 Palangka Raya, Kalimantan Tengah. The study applied a quasi-experimental research design. To be research participants, 30 students of the natural science class were as an experiment group, and 30 students of the social science class were as a control group taken with a cluster random sampling. Data were collected using the reading test and questionnaire. The collected data were then analyzed using one-way ANOVA with SPSS 20. The results showed that GTM has a significant effect on students reading comprehension and reading motivation. It was found that the degree of freedom between group $(\mathrm{DFb})=2$, the degree of freedom within group $(\mathrm{DFw})=87\left(\mathrm{~T}_{\text {table }}=1.99\right)$, and $\mathrm{F}_{\text {value }}$ was 37.019. It showed that $\mathrm{F}_{\text {value }}$ was higher than $\mathrm{T}_{\text {table }}$ $(37.019>1.99)$. It means that Ha was accepted and Ho was rejected.
\end{abstract}

Keywords: grammar-translation method; reading comprehension; reading motivation

\section{INTRODUCTION}

This research topic is important to research because it would help teachers use the teaching method, especially on the narrative text. This method tends to be an applicable method and easy to conduct. It could also be the first intellectual act the learners can use when they cannot express themselves in the target language (Aqel, 2013; Applegate \& Applegate, 2010).

According to Aqel (2013), the grammar-translation method (GTM) is an important teaching methodology for teachers to adapt to teach English as a second language. The researchers should highlight the advantage or disadvantages of this method. Many reasons are behind that, first, because it is an applicable method and easy to conduct. Second, the first intellectual act the learners can use when they feel unable to express by the target language is interpreting by native language, and that exactly the core of this method. Third, the great benefit of joining the knowledge of both languages free the learner from the ambiguity of the target language. After all, the researcher recommended that after exhibiting the language skills and the grammatical rules, the usefulness of translation decreases.

Therefore, applying grammatical structure or practicing the language skills, in general, should be in the target language to confirm the needed forms that the learners must develop to achieve the best results they are looking for. This also becomes the reason why this experiment is important. It is to give information about the grammar-translation method, including how to use this high school education method. It will help teachers implement this method while teaching in their class, and this experiment also helps teachers decide whether it is good to use the grammar-translation method in a narrative text (Aqel, 2013; Gambrell, 2011). The students' reading comprehension through the grammar-translation method concludes that students' reading comprehension through grammar translation improves significantly (Megawati, 2017; Legge et al., 2001). 
IJRETAL

International Journal of Research on English Teaching and Applied Linguistics, Vol. 1, No.1, June 2020

English class has its own method or technique. It depends on what level you are (Freeman et al., 2011). In the university levels use, it depends on what skill that lecturer teaches; for example, in speaking skills, the lecturer usually used role-play method and the listening skills lecturer usually used audio-lingual method (Sharma, 2001). On the other hand, it would be different. In senior high school, the use of method or technique will depend on what materials will be taught, such as the materials about a narrative text or something else the teacher usually uses two share-two stay method and commonly used traditional learning technique (Bennette, 2001; Westwood, 2008). That is why in this research, the researcher takes the effect of grammar-translation method (GTM) as a solution to use in teaching narrative text toward students reading comprehension and their reading motivation as the topic for discussion of this research.

Talking about reading motivation, it is the motivational drive to read, an area of interest in the field of education (McGeown et al., 2012). Studying and implementing the conditions under which students are motivated to read is important in the process of teaching and fostering learning (Serravallo, 2010). Therefore, in English learning, both reading and writing motivation are the processes to put more effort into reading and writing activities.

The differences between the present research and the previous studies are in the field of study. The previous research mostly took place in junior high school and senior high school. Also, those researches focused on the effect of GTM on students reading comprehension only. However, this research focuses on two subjects, which are students reading comprehension and reading motivation. This study addresses the research questions as follows, "Is there any effect of GTM on students' reading comprehension?", is there any effect of GTM on students' reading motivation?", and is there any effect of GTM on students' reading comprehension and reading motivation?"

\section{RESEARCH METHOD}

\section{Research Design}

This research applied the quantitative method because a quantitative approach is the right approach for a numbering objective (Creswell, 2014). This research aimed to investigate the effect of the grammar-translation method. It needed the before and after data, which was conducted in two groups. They are experimental and control groups. The experimental group is the group that received the treatment using GTM on comprehend reading materials and motivation, while the control group is the group that was not be exposed to the experimental treatment. It was as said that in the most basic experimental design, the group receiving the treatment is called the experimental group and the other group the control group (Bordens \& Abbott, 2011).

\section{Participants}

This research population was the first-grade students of SMAN 4 Palangka Raya in Kalimantan Tengah, Indonesia. As suggested by Schreiber and Asber-self (2010), the population in social science research refers to all of your potential participants; think of it as the whole group of people in which you are interested". As the samples, it took two classes: the total number of the sample was 60 students, in which it was 30 students of IPA class as the experimental group and 30 students of IPS class as the control group. Bordens and Abbott (2011) said that a sample is a small subgroup chosen from the larger population. The sample of participants in this study was part of the population. All possess some characteristic or characteristics that make them members of the sample group (Schreiber \&Asber-self, 2010). 
IJRETAL

International Journal of Research on English Teaching and Applied Linguistics, Vol. 1, No.1, June 2020

\section{Instruments}

In this study, the data were taken using a test. The test was used to know the result of the effectiveness using the Grammar-Translation Method of SMAN 4 Palangka Raya's first grade. To get information about students' scores, it was used narrative text multiple choices test. The reason the researcher used multiple-choice is that the teacher commonly used multiple choice. The researcher used a narrative text on a literal reading level because it was considered that the students were in a high-level school.

A questionnaire was a research instrument consisting of a series of questions for the purpose of gathering information from respondents. To get information about students' reading motivation, it was adapted from a questionnaire developed by Coddington and Guthrie (2009). The questionnaire was used to collect data on the point of view of students about their reading motivation. Total of the questionnaire are 13 items: item 1 asked students how students handle hard word when reading; item 2 asked students how good students remembered what they read; item 3 asked students confident in reading; item 4 asked students confident on hard word comprehension; item 5 asked students confidently on hard word comprehension; item 6 asked students were feeling when reading text; item 7 asked students feeling when reading text; item 8 asked students feeling when reading text in some places; item 9 asked students were feeling when reading text in some places; item 10 asked students feeling when reading text in some places; item 11 asked students problems when reading text; item 12 asked students problems when reading text; and item 13 asked students problems when reading text.

To make a score gotten from the questionnaire, it was used scales of strongly disagree (1), disagree (2), Neutral (3), Agree (4), and strongly agree (5). A higher score indicated higher motivation and lower score indicated lower motivation of the students which based on the criteria of score interpretation: 1) $0 \%-20 \%$ (Very Low); 2) $21 \%-40 \%$ (Low); 3) $41 \%-60 \%$ (Moderately); 4) 61\% - 80\%(Strong); and 5) 81\% - 100\% (Very Strong) (Coddington \& Guthrie, 2009).

\section{Data Collection}

To get the data, it used some procedures. Firstly, it chose the study population and then determined two groups: the first group was the experiment group, and the second group was the control group. After getting the research permission from SMAN 4 Palangka Raya, it conducted pretest to both groups. After the pretest was conducted, it checked the pretest result. The researchers then gave the experimental group treatment using the grammar-translation method (GTM), and the control group was taught using the conventional teaching method. Finally, after giving the treatment, the researchers gave posttest for both the experiment and control groups and evaluated the test results.

\section{Data Analysis}

To analyze the data that have been collected in this study, it used procedures. It gave scores of the students' test results by using the formula adapted from Sudijono (2012). Then, the data were calculated by using one-way ANOVA in SPSS 20. After that, it interpreted the result of the calculation of one-way ANOVA. Finally, the results were discussed and concluded. 
IJRETAL

International Journal of Research on English Teaching and Applied Linguistics, Vol. 1, No.1, June 2020

\section{FINDINGS}

Before analyzing the data, the normality and homogeneity of the data were measured. The Kolmogorov-Smirnov test was used to measure the data's normality because the number of the sample was 60 students. If significance $>0.05$, the data is normally distributed, but if significance $<0.05$, it is not normally distributed. Based on the Normality output Test, the experiment class's significance value was 0.005 , while the significance value for the control class was 0.000. It can be concluded the data for experiment class, and control class was not normally distributed. It is because the significance value was lower than 0.05 . In addition, the researchers also calculated the normality test from the students' reading motivation questionnaire with the following results. Based on the Normality output Test, the significance value for the experiment class was 0.001 , while the significance value for the control class was 0.106 . It can be concluded that the data for the experiment class was not of normal significance because the significance value was lower than 0.05 . Meanwhile, the control class was normally distributed because the significance value was greater than 0.05 .

The homogeneity of the pre-test and post-test were measured as well. The value of (probably value/critical value) from pre-test of experiment and control class on the homogeneity of variance in sig column was 0.023. It means that the experiment class and control class has not the same variant or not homogeneous because the value was lower or $r=0.023<0.05$. Besides, the researcher also calculated the homogeneity test on students' post-test scores of the experiment class. Based on the SPSS 20 program output above, the value of (probably value/ critical value) from post-test of the experiment and control class on the homogeneity of variance in the sig column was 0.926 . The experiment class and control class have the same variant or homogeneous because the value was higher or $r=0.926>0.05$.

In addition, the researchers also calculated the homogeneity test from the students' reading motivation questionnaire with the following results. The value of (probably value/ critical value) from students' reading motivation questionnaire test on the homogeneity of variance in sig column was 0.002 . It means that the experiment class and control class did not have the same variant or not homogeneous. It is because the value was lower or $r=0.002<0.05$.

The researchers used One-Way ANOVA to test the hypothesis with a significance level of 0.05 . The post-test experiment and control class result and the result of the reading motivation of the experiment class were presented in the following descriptive statistics shown in Table 1. 
IJRETAL

International Journal of Research on English Teaching and Applied Linguistics, Vol. 1, No.1, June 2020

Table 1. Result of Post-test Experiment and Control Class, and Result of Reading Motivation of Experiment Class

\begin{tabular}{|c|c|c|c|c|c|c|c|c|}
\hline \multicolumn{9}{|c|}{ Descriptive } \\
\hline \multicolumn{9}{|c|}{ Score of Reading Test and Questionnaire Test } \\
\hline & \multirow[t]{2}{*}{$\mathrm{N}$} & \multirow[t]{2}{*}{ Mean } & \multirow[t]{2}{*}{$\begin{array}{c}\text { Std. } \\
\text { Deviation }\end{array}$} & \multirow[t]{2}{*}{$\begin{array}{l}\text { Std. } \\
\text { Error }\end{array}$} & \multicolumn{2}{|c|}{$\begin{array}{c}95 \% \\
\text { Confidence } \\
\text { Interval for } \\
\text { Mean }\end{array}$} & \multirow[t]{2}{*}{$\begin{array}{c}\text { Minim } \\
\text { um }\end{array}$} & \multirow[t]{2}{*}{$\begin{array}{l}\text { Maxi } \\
\text { mum }\end{array}$} \\
\hline & & & & & $\begin{array}{l}\text { Lower } \\
\text { Bound }\end{array}$ & $\begin{array}{l}\text { Upper } \\
\text { Bound }\end{array}$ & & \\
\hline $\begin{array}{l}\text { Post-test } \\
\text { Exp. }\end{array}$ & 30 & 66.23 & 12.082 & 2.206 & 61.72 & 70.74 & 53 & 87 \\
\hline $\begin{array}{l}\text { Post-test } \\
\text { Con. }\end{array}$ & 30 & 52.47 & 15.986 & 2.919 & 46.50 & 58.44 & 13 & 87 \\
\hline $\begin{array}{l}\text { Reading } \\
\text { Motivation } \\
\text { of Exp. }\end{array}$ & 30 & 40.30 & 2.781 & 0.508 & 39.26 & 41.34 & 37 & 49 \\
\hline Total & 90 & 53.00 & 15.712 & 1.656 & 49.71 & 56.29 & 13 & 87 \\
\hline
\end{tabular}

Table 1 shows that the result of the standard deviation calculation of experiment class on reading comprehension test was 12.082, the result of the standard error of mean calculation was 2.206, and the result of mean was 66.23. Then, the result of the standard deviation calculation of the control class on the reading comprehension test was 15.986, the result of the standard error of the mean was 2.919, and the result of the mean was 52.47. On the other hand, the result of the standard deviation of the experiment class on the reading motivation test was 2.781 , the result of the standard error of the mean was 0.508 , and the result of the mean was 40.30. In addition, Table 2 shows was the result of one-way ANOVA calculations. 
IJRETAL

International Journal of Research on English Teaching and Applied Linguistics, Vol. 1, No.1, June 2020

Table 2. The Result of Post-test Experiment and Control Class, and Result of Reading Motivation of Experiment Class

\begin{tabular}{|c|c|c|c|c|c|}
\hline \multicolumn{7}{|c|}{ ANOVA } \\
\hline & $\begin{array}{c}\text { Sum of } \\
\text { Squares }\end{array}$ & df & Mean Square & F & Sig. \\
\hline Between Groups & 10100.867 & 2 & 5050.433 & 37.019 & .000 \\
\hline Within Groups & 11869.133 & 87 & 136.427 & & \\
\hline Total & 21970.000 & 89 & & & \\
\hline
\end{tabular}

It was set up of the criteria that Ho is accepted when $\mathrm{F}$ value, $<$ Ftable, and Ho is rejected when $\mathrm{F}$ value, $>\mathrm{F}$ table. Ha's criteria are then accepted when $\mathrm{F}$ value, $>\mathrm{F}$ table, and $\mathrm{Ha}$ is rejected when F-value, $<$ Ftable.

Table 2 shows the result of one-way ANOVA. Based on Table 2, it was found that Degree of Freedom between-group $(\mathrm{DFb})=2$ and Degree of Freedom within the group $(\mathrm{DFw})=87($ Ftable $=3.10)$, and also Fvalue was 37.019. It shows that Fvalue was higher than Ftable (37.019>3.10). So, Ho was rejected and Ha was accepted. There were significant differences among groups after treatment, with Fvalue $=37.019$ and the significant level was lower than alpha $(0.000<0.05)$. It means that the grammartranslation method (GTM) has a significant effect on students' reading comprehension and reading motivation.

Knowing that there was a significant difference among groups after doing treatment, the researcher needed to test the hypotheses. Because One-Way ANOVA was only to know that there was significant differences among groups, not for know where the differences among groups. To answer the problems of the study and hypotheses test, the researcher applied Post Hoc Tests.

The hypothesis test using the SPSS 20 program by applying Post Hoc Tests from the result of the post-test experiment and control class, and the result of the experimental class's reading motivation is presented in Table 3. 
IJRETAL

International Journal of Research on English Teaching and Applied Linguistics, Vol. 1, No.1, June 2020

Table 3. The Calculation of Post Hoc Tests

\begin{tabular}{|c|c|c|c|c|c|c|}
\hline \multicolumn{7}{|c|}{ Multiple Comparisons } \\
\hline \multicolumn{7}{|c|}{ Dependent Variable: Score of Reading Test and Questionnaire Test } \\
\hline \multirow[t]{2}{*}{ (I) Class } & \multirow[t]{2}{*}{ (J) Class } & \multirow{2}{*}{$\begin{array}{c}\text { Mean } \\
\text { Difference } \\
(\mathrm{I}-\mathrm{J})\end{array}$} & \multirow{2}{*}{$\begin{array}{l}\text { Std. } \\
\text { Error }\end{array}$} & \multirow[t]{2}{*}{ Sig. } & \multicolumn{2}{|c|}{$\begin{array}{c}95 \% \\
\text { Confidence } \\
\text { Interval }\end{array}$} \\
\hline & & & & & $\begin{array}{l}\text { Lower } \\
\text { Bound }\end{array}$ & $\begin{array}{l}\text { Upper } \\
\text { Bound }\end{array}$ \\
\hline \multirow[b]{2}{*}{ Post-test Exp. } & Post-test Con. & $13.767^{*}$ & 3.659 & .001 & 4.95 & 22.58 \\
\hline & $\begin{array}{c}\text { Reading Motivation of } \\
\text { Exp. }\end{array}$ & $25.933^{*}$ & 2.264 & .000 & 20.37 & 31.50 \\
\hline \multirow{2}{*}{ Post-test Con. } & Post-test Exp. & $-13.767^{*}$ & 3.659 & .001 & -22.58 & -4.95 \\
\hline & $\begin{array}{l}\text { Reading Motivation of } \\
\text { Exp. }\end{array}$ & $12.167^{*}$ & 2.963 & .001 & 4.87 & 19.46 \\
\hline \multirow{2}{*}{$\begin{array}{l}\text { Reading } \\
\text { Motivation of } \\
\text { Exp. }\end{array}$} & Post-test Exp. & $-25.933^{*}$ & 2.264 & .000 & -31.50 & -20.37 \\
\hline & Post-test Con. & $-12.167^{*}$ & 2.963 & .001 & -19.46 & -4.87 \\
\hline
\end{tabular}

It was set up of the criteria that Ho is accepted when the significant value is higher than alpha $(\alpha)(0.05)$, and Ho is refused when the significant value is lower than alpha $(\alpha)(0.05)$. So, based on the calculation of Post Hoc Tests above, it can be concluded.

First, the experiment class of reading comprehension shows the significant value was lower than alpha $(0.001<0.05)$. It means that there was a significant effect of the GrammarTranslation Method (GTM) on students' reading comprehension. Thus, Ha stated that the grammar-translation method affects students' comprehension on reading at the first grade of SMAN 4 Palangka Raya was accepted and Ho stated that the grammar-translation method does not affect students' comprehension on reading due the process take too long at the first grade of SMAN 4 Palangka Raya was rejected.

Second, the experiment class's reading motivation showed the significant value was lower than alpha $(0.000<0.05)$. It meant that, there was a significant effect of the GrammarTranslation Method (GTM) on students' reading motivation. Therefore, Ha state that grammar translation method has significant effect in students' reading motivation on reading at the first grade of SMAN 4 Palangka Raya was accepted and Ho state that grammar translation method has no effect toward students' motivation on reading due the process take too long at the first grade of SMAN 4 Palangka Raya was rejected. 
IJRETAL

International Journal of Research on English Teaching and Applied Linguistics, Vol. 1, No.1, June 2020

Third, the significant effect of experiment class by using Grammar Translation Method (GTM) toward reading comprehension and reading motivation of students showed the significant value was lower than alpha $(0.000<0.05)$. It meant that, there were significant effect of Grammar Translation Method (GTM) towards reading comprehension and reading motivation. While, Ha state that grammar translation method has significant effect in students' comprehension and their motivation on reading at the first grade of SMAN 4 Palangka Raya was accepted and Ho state that grammar translation method has no effect toward students' comprehension and their motivation on reading due the process take too long at the first grade of SMAN 4 Palangka Raya.

\section{DISCUSSION}

Based on the analysis result, it can be interpreted that teaching reading using Grammar Translation Method (GTM) was more effective toward students' reading comprehension than teaching reading without using GTM. It showed in the result of significant value. Teaching reading using GTM was more effective toward students' reading motivation than teaching reading without using GTM. It showed in the result of significant value. Teaching reading using GTM was more effective toward students' reading comprehension and reading motivation than teaching reading without using GTM. It also showed in the result of significant value.

Teaching reading using GTM was more effective toward students' reading comprehension and reading motivation than teaching reading without using GTM. This finding has the same results with some previous studies. First, the previous study by Megawati (2017) showed that the ability of students' reading comprehension through GTM improved significantly. This revealed when the students could answer the question, and it can read the text fluently. GTM is proved to be effective in improving students' reading comprehension.

Another study was conducted by Fatmala (2012). The research-based on Larsen Freeman Grammar Translation Method was used to help students read and appreciate foreign language literature. It also hoped that through the study of the target language's grammar, students would become more familiar with the grammar of their native language and that this familiarity would help them speak and write their native language and better. The result of the test showed an average score of the students understanding in reading comprehension. The previous study stated that there was a significant influence in applying the grammar-translation method on the students' understanding in reading comprehension. GTM is one of the methods that can increase students' reading skills.

\section{CONCLUSION}

Teaching reading using the Grammar-Translation Method (GTM) was more effective toward students' reading comprehension and reading motivation than teaching reading without using GTM. Therefore, GTM is one of the applicable methods in teaching reading comprehension at the level of high schools in this research it is recommended for students, teachers, and researchers. It is suggested that senior high school students keep reading activities because reading is very important and can increase their reading comprehension. The teachers should guide and encourage their students to do the reading activities and keep practicing the reading fluency using GTM because of its strength. Finally, for future research, it is suggested to investigate the effect of GTM on students' reading comprehension and motivation and the factors that could affect both variables. It is better if future research has larger samples. 
IJRETAL

International Journal of Research on English Teaching and Applied Linguistics, Vol. 1, No.1, June 2020

\section{REFERENCES}

Applegate, A. J., \& Applegate, M. D. (2010). A study of thoughtful literacy and the motivation to read. Reading Teacher, 64(4), 226-234.

Aqel, I. M. (2013). The effect of using grammar-translation method on acquiring English as a foreign language. International Journal of Asian Social Science, 3(12), 2469-2476

Bennette, J. (2001). A course in light speed reading (5 $5^{\text {th }}$ ed.). Oxford: Oxford University Press.

Bordens, K. S., \& Abbott, B. B. (2011). Research design and methods: a process approach ( $8^{\text {th }}$ ed.). New York: The McGraw-Hill Companies, Inc.

Coddington, C. S., \& Guthrie, J. T. (2009). Teacher and student perceptions of boys' and girls' reading motivation. Reading Psychology, 30, 225-249.

Creswell, J. W. (2014). Research design: qualitative, quantitative, and mixed methods approaches. Singapore: SAGE Publications Asia-Pacific Pte. Ltd.

Fatmala, E. (2012). The influence of the application of grammar translation method (GTM) on the students' understanding in reading comprehension at the first year students of MTs Wathoniyah Gintung Lor - Cirebon. Unpublished Thesis, English Education Department, Syekh Nurjati State Institute, Cirebon

Freeman, Larsen, D., \& Anderson, M. (2011). Techniques \& Principles in Language Teaching ( $3^{\text {rd }}$ ed.). Oxford: Oxford University Press.

Gambrell, L. B. (2011). Motivation in the school reading curriculum. Journal of Reading Education, 37(1), 5-14.

Legge, G. E., Mansfield, J. S., \& Chung, S. T. (2001). Linking letter recognition to reading speed in central and peripheral vision. Vision Research, 41(6), 725-743.

McGeown, S., Goodwin, H., Henderson, N., \& Wright, P. (2012). Gender differences in reading motivation: does sex or gender identity provide a better account? Journal of Research in Reading, 35(3), 328-336.

Megawati. (2017). The improving students' reading comprehension through grammar translation method. Unpublished Thesis, the English Education Department, Kusumanegara, Jakarta

Schreiber, J. B., \& Asner-Self, K. (2010). Educational research (1 ${ }^{\text {st }}$ ed.). New York: Wiley

Serravallo, J. (2010). Teaching reading in small group. New York: Heinemann.

Sharma, C. T. (2001). Modern methods of university and college teaching (1 ${ }^{\text {st }}$ ed.). New Delhi: Sarup \& Sons.

Sudijono, A. (2012). Pengantar evaluasi pendidikan. Jakarta: PT. Raja Grafindo Persada.

Westwood, P. (2008). What teachers need to know about reading and writing difficulties ( $1^{\text {st }}$ ed.). Australia, Acer Press. 